\title{
SEIS DE JULHO: A GREVE DOS PETROLEIROS DE 1983 CONTRA O GOVERNO FIGUEIREDO E O FUNDO MONETÁRIO INTERNACIONAL
}

\author{
Carlos Lucena ${ }^{1}$ \\ Lurdes Lucena ${ }^{2}$ \\ Fabiane Santana Previtali. ${ }^{3}$ \\ Robson Luiz de França ${ }^{4}$ \\ Adriana Omena ${ }^{5}$
}

\section{RESUMO}

Este artigo analisa a greve dos petroleiros de 1983 contra o Fundo Monetário Internacional. Demonstra a existência de um processo de crise internacional do capitalismo e seus impactos nos países centrais e periféricos. Trabalha a tese que a greve atentou contra processos internacionais acumulativos do capital em sua forma financeira que marcaram uma fase embrionária da instauração do neoliberalismo no Brasil.

Palavras-chave: Petroleiros; Ditadura Militar; Fundo Monetário Internacional; Teoria do Valor.

\section{SIX OF JULY: A STRIKE OIL OF 1983 AGAINST THE GOVERNMENT AND FIGUEIREDO THE INTERNATIONAL MONETARY FUND}

\begin{abstract}
This article analyzes the 1983 oil strike against the International Monetary Fund. Demonstrates the existence of a process of international crisis of capitalism and its impact on the central and peripheral countries. Works the thesis that the strike undermined the accumulative capital in its financial form that marked an early stage of the introduction of neoliberalism in Brazil international processes.
\end{abstract}

Keyworks: Tankers; Military Dictatorship; International Monetary Fund; Theory of Value

\section{Introdução}

A greve dos petroleiros de 1983 desenvolveu-se em meio a um processo de reestruturação do capital em âmbito internacional como resposta à falência do sistema Breton Woods sustentado pelos Estados Unidos e as crises do petróleo no Oriente Médio. O Brasil viveu um período conturbado movido pela recessão econômica e a perda de popularidade do governo militar-civil.

Esse foi um período histórico contraditório. Por um lado, o crescimento do sindicalismo autêntico em crítica radical aos sindicatos corporativistas imperantes no pós 1964. Por outro lado, a submissão política governamental aos imperativos do Fundo Monetário Internacional manifestos na abertura da economia nacional aos setores transnacionais como condição imposta para a obtenção de novos empréstimos voltados à continuidade do pagamento dos juros da dívida externa crescente.

Esse movimento paredista expressou a resistência de parcela desses trabalhadores ao amplo processo de reorganização do capital para a superação de sua crise em âmbito internacional e seus desdobramentos no Brasil. O escopo de suas reivindicações assumiu 
uma dimensão política de contestação ao governo militar-civil e o Fundo Monetário Internacional. Ela ocorreu em resistência ao lançamento do denominado "pacote das estatais", editado em maio de 1983, através do Decreto Lei $\mathrm{N}^{\circ} 2024$, propondo redução de salários e benefícios dos trabalhadores das estatais, um corte de $10 \%$ no efetivo funcional desse segmento, proibição de novas contratações, entre outras medidas.

O lançamento do "pacote das estatais" acirrou o debate incipiente até então no Brasil sobre o conflito entre o nacional desenvolvimentismo e o neoliberalismo. O fim do "milagre econômico" manifesto pelos rumos econômicos e políticos tomados pelo governo militar-civil expressos no III Plano Nacional de Desenvolvimento acirraram o debate sobre o presente e o futuro do Brasil. O "pacote da estatais" foi a sinalização concreta do abandono da política de substituição de importações, atendendo às determinações do Fundo Monetário Internacional voltadas à privatização das empresas estatais e, consequentemente, a abertura do mercado nacional aos grupos privados transnacionais.

A fragilização econômica brasileira em face à crise internacional fortaleceu os embates internos sobre a adoção de princípios neoliberais, ainda que de forma embrionária, como saída para a recuperação brasileira em âmbito nacional e internacional. A visita de F. V. Hayek ao Brasil em 1981 para um conjunto de conferências e debates na Universidade de Brasília marcou o início da discussão do projeto neoliberal no Brasil.

As exigências do FMI fragilizaram a economia brasileira atingindo diretamente as empresas estatais. A impossibilidade de transferência do aumento dos custos para os preços acompanhado pelo entendimento ao qual os investimentos realizados eram entendidos como déficit público desestruturaram as empresas estatais. O governo militarcivil utilizou as empresas estatais como garantia de financiamento da divida brasileira expressa pelo II Plano Nacional de Desenvolvimento. O crescente endividamento dessas empresas comprometeu seu funcionamento e autogestão, fortalecendo os discursos neoliberais defensores das forças do mercado como reguladoras das relações de troca capitalista.

A ideologia da eficiência neoliberal ganhou força no país sustentada pela incapacidade do governo militar-civil em promover melhorias sociais. O nacionalismo, apregoado de forma ideológica e violenta na década de 1970, passou por um radical processo de ruptura marcado pelo abandono da política de substituição de importações. Um amplo debate ganhou corpo no Brasil na década de 1980. Por um lado, os defensores de políticas liberais, apoiados na ineficiência e baixa popularidade do regime militar, propondo a abertura da economia como saída para o Brasil. Por outro lado, os nacionalistas divididos em dois principais grupos distintos entre si. O primeiro grupo, composto por segmentos sociais e partidos sustentados no pensamento de Vargas e JK, entendeu o nacionalismo como caminho único para o crescimento econômico do Brasil. A manutenção da política de substituição de importações era estratégica para aproximar o país das nações centrais existentes no planeta. O segundo, formado por partidos críticos à ditadura, intelectuais orgânicos da classe trabalhadora e sindicatos autênticos em defesa da centralidade do Estado como estratégia para a emancipação social.

Os trabalhadores das empresas estatais representados por nacionalistas de ambos os segmentos, construíram uma frente de resistência às mudanças econômicas internas e externas em curso no Brasil. Na prática, os funcionários das empresas estatais se mobilizaram no intuito de construir uma greve como demonstração de força sem definitivamente obter um consenso sobre a data da paralisação. No início dos anos 80 do século XX ocorreu um jogo retórico político composto por blefes, possibilidades, limites e resistências. 
A desconfiança dos setores nacionalistas não ocorreu ao acaso. O governo Figueiredo sinalizou o abandono da política de substituição de importações criando o Programa Nacional de Desburocratização através do Decreto N. 83740 de julho de 1979 e, posteriormente, o Decreto 86215, de 15 de julho de 1981 que fixou as normas para o processo de privatização nomeando uma comissão interministerial para esse fim. $\mathrm{O}$ conjunto de mobilizações dos trabalhadores e protestos de segmentos nacionalistas levou o governo a retirar o decreto Lei 2024.

O governo militar-civil em resposta à ampla mobilização dos trabalhadores, decretou o decreto Lei № 2036 em 28 de Junho de 1983 através do qual as mudanças na política governamental voltada à gestão das empresas estatais atingiriam apenas os novos trabalhadores. No referido Decreto, denominado pelos sindicalistas como "pacote das estatais", alguns artigos e incisos merecem destaque.

O Decreto Lei № 2036/83 limitou os salários dos funcionários públicos e trabalhadores das empresas estatais. Os artigos $1^{\circ}$ e $13^{\circ}$ legislaram sobre o tema em questão. Merece destaque, a tentativa de desmobilização dos trabalhadores contida no parágrafo único do artigo $13^{\circ}$, aplicando as mudanças aos servidores públicos e trabalhadores das empresas estatais admitidos após a promulgação do Decreto Lei.

Art. $1^{\circ}$ A nenhum servidor, empregado ou dirigente da Administração Pública Direta e Autárquica da União e das respectivas entidades estatais, bem como aos do Distrito Federal e dos Territórios, será paga, no País, remuneração mensal superior à importância fixada, a título de subsídio e representação, para o Presidente da República.

Art. $13^{\circ}$ As entidades estatais não poderão pagar a seus servidores ou empregados, em cada ano do calendário, mais de 13 (treze) salários, neles compreendida a gratificação de Natal (Lei $n^{\circ} 4.090$, de 13 de julho de 1962).

Parágrafo único. Aos servidores ou empregados admitidos até a data do início da vigência deste Decreto-lei, ficam assegurados, como vantagem pessoal nominalmente identificável, os adicionais e gratificações de natureza estatutária, regulamentar ou regimental, atualmente existentes, bem como os benefícios e vantagens concedidos por lei federal, observadas as demais disposições deste Decreto-lei.

Em conjunto com a instauração do "teto salarial" determinou a redução de benefícios oferecidos aos servidores e trabalhadores das empresas estatais expresso nos $\operatorname{artigos} 14^{\circ}, 15^{\circ}, 16^{\circ}, 17^{\circ}$ e $23^{\circ}$.

Art. $14^{\circ}$. vedado às entidades estatais conceder a seus dirigentes, servidores ou empregados os seguintes benefícios ou vantagens, salvo se resultarem de imposição de lei federal:

I) empréstimo pessoal, financiamento de veículos ainda que relacionado com o exercício do emprego, cargo ou função, financiamento ou locação de imóveis e de bens duráveis, auxíliomoradia, auxílio-financeiro, auxílio-natalidade, auxílio-funeral, auxílio-casamento, cartões de crédito, bem como benefícios e vantagens análogos, ou auxílios de qualquer espécie, ressalvado o disposto nos parágrafos deste artigo;

II)participações nos lucros, ainda que sob a forma de resultado de balanço, de produtividade, de incentivo à produtividade, de eficiência, bem como a gratificação de assiduidade, e análogas, observado quanto aos servidores ou empregados admitidos até a data 
de vigência deste Decreto-lei o disposto no parágrafo único do Art. $13^{\circ}$.

Art. 15. É vedado, ainda, às entidades estatais:

III) criar benefícios ou vantagens não previstas nos seus atuais estatutos, regulamentos ou regimentos, na data do início da vigência deste Decreto-lei, exceto quando resultarem de determinação de lei federal.

Art. $16^{\circ}$. Em nenhuma hipótese as entidades estatais concederão aos servidores ou empregados admitidos após a data do início da vigência deste Decreto-lei, os adicionais e gratificações de que trata o parágrafo único do art. 13, nem quaisquer benefícios ou vantagens assegurados aos admitidos anteriormente, exceto os que constarem dos novos planos de Cargos e Salários e de Benefícios e Vantagens aprovados pelo Conselho Nacional de Política Salarial - CNPS.

Art. 17. A assistência médico-hospitalar e odontológica, a assistência social e a contribuição para associação de empregados ficam sujeitas à exigência de recursos especificamente destinados e à prévia e expressa aprovação do órgão de administração superior de cada entidade, ouvido previamente o CNPS.

Art. 23. Ao aprovar a adequação dos Planos de Cargos e Salários e de Benefícios e Vantagens às disposições deste Decreto-lei, o CNPS procederá de modo a que o adicional por tempo de serviço não ultrapasse $1 \%$ (um por cento) do salário base por ano de efetivo exercício, até o limite de $35 \%$ (trinta e cinco por cento), qualquer que seja a periodicidade estabelecida para sua concessão, respeitadas as situações jurídicas constituídas anteriormente à vigência deste Decreto-lei.

Parágrafo único. A partir da publicação deste Decreto-lei, fica vedada a concessão do adicional por tempo de serviço.

A restrição das promoções e concessão de adicionais de periculosidade acompanhada da proibição da elevação das vantagens profissionais foram prescritos nos $\operatorname{artigos} 18^{\circ}$ e $19^{\circ}$.

Art. 18. Até 31 de dezembro de 1984, ficam suspensos, no âmbito das entidades estatais:

a) aumentos de vantagens;

b) promoções, salvo as de caráter automático; e

c) os acessos, exceto os destinados ao preenchimento de cargos vagos.

Art. 19. Após a vigência deste Decreto-lei, os adicionais de insalubridade e de periculosidade serão concedidos com a estrita observância do disposto nos arts. 189 e 193 da Consolidação das Leis do Trabalho.

Parágrafo único. Será efetuado contrato de seguro para cobertura dos eventuais riscos, em favor dos servidores ou empregados admitidos após a vigência deste Decreto-lei, que, de forma ocasional, se encontrem em situação de periculosidade.

Foi o artigo $26^{\circ}$ do Decreto Lei 2036/83, que demonstrou o atrelamento governamental aos imperativos do FMI manifestos na liberalização da economia e consequente redução da centralidade das empresas estatais no país.

Art. 26. As entidades estatais deverão realizar uma redução de seus gastos de custeio, excetuados os relacionados com matérias primas e variação de estoques, no valor correspondente a 5\% (cinco por cento) dos gastos totais, 
dessa natureza, previstos no orçamento aprovado pela Secretaria de Controle das Empresas Estatais - SEST, para cada um dos seguintes períodos:

I - julho a dezembro de 1983 ;

II - janeiro a junho de 1984.

Parágrafo único. Somente por ato do Presidente da República poderá ser alterado o percentual previsto neste artigo, nos casos em que for impossível à entidade estatal realizar a redução acima estabelecida.

O "pacote das estatais" acirrou a mobilização dos petroleiros. Em Paulínia, na primeira e segunda assembleia estiveram presentes respectivamente 400 e depois 600 trabalhadores que sinalizaram pela construção de uma greve de resistência. Os dirigentes sindicais entenderam que o decreto assinado pelo Presidente Figueiredo instituía a demissão em massa nas empresas estatais. Isto porque, apesar de manter aos antigos funcionários todos os direitos adquiridos, exigia, ao mesmo tempo, uma redução semestral de 5\% do seu valor total de custeio. Isso representou, na avaliação dos sindicalistas, a demissão de $15 \%$ do efetivo atual da Petrobrás, ou então a substituição de $30 \%$ dos seus funcionários com novas contratações pela metade dos salários atuais. Além disso, estava em questão a retirada de direitos históricos dos trabalhadores tais quais a gratificação de férias e o adicional de periculosidade para trabalhos em regiões insalubres.

Um conjunto de mobilizações foi organizado pelo sindicato da categoria voltadas a debater com os trabalhadores de base o "pacote das estatais" e como seus desdobramentos atingiriam suas condições de trabalho e a própria existência da Petrobrás. A resistência começou a ser organizada interna e externamente aos muros das Refinarias de Paulínia e Landulpho Alves, na Bahia. Isso se explica nas alianças sindicais motivadas pelo crescimento do sindicalismo autêntico no Brasil. A fundação do então jovem Partido dos Trabalhadores em 1979 e os debates, acordos e alianças de diferentes tendências sindicais para a fundação da futura Central Única dos Trabalhadores fortaleceram o estabelecimento de pactos políticos de enfrentamento ao governo militar-civil.

Foi assim que se construiu a aliança entre os petroleiros e os metalúrgicos do $\mathrm{ABCD}$, cujas diretorias eram compostas por diretores que em sua maioria pertenciam à "Articulação", tendência política interna do Partido dos Trabalhadores. Essa afirmação se justifica na realização de uma assembleia conjunta entre petroleiros e metalúrgicos ocorrida em 03 de julho de 1983 à qual foi votado que caso os primeiros entrassem em greve, essa ação seria acompanhada pelos trabalhadores do ABCD paulista.

A greve dos petroleiros foi construída com o aumento gradativo das mobilizações. Ocorreu a luta pela licença maternidade em que todas as mulheres petroleiras foram trabalhar de saiais. Os petroleiros usaram tarjas negras e não marcaram o cartão de ponto para protestar contra a nomeação de Shigeaki Ueki como presidente da Petrobrás. Ocorreram greves de fome, negação do uso de identidade funcional, minutos de silêncio, passeatas e uma vigília de 36 horas em que os trabalhadores se negaram a sair da refinaria. A vigília teve o objetivo de desestruturar a gerência local e assumir as deliberações do órgão em assembleia, colocando a fábrica sob o controle do sindicato.

A construção da greve atendeu a expectativas políticas diferenciadas no cotidiano dos petroleiros. Por um lado, um conjunto de militantes atentos às mudanças políticas no Brasil e o papel dos trabalhadores nesse processo, por outro lado, um conjunto de trabalhadores não politizados, cujos limites de compreensão política se limitavam a questões do cotidiano do trabalho. Da mesma forma, em âmbito nacional, existiam posições diferenciadas quanto ao encaminhamento das lutas sindicais contra o governo militar civil. 
O movimento sindical brasileiro passou por mudanças na década de 70. Apesar da predominância do sindicalismo corporativo no país, outra concepção sindical foi gestada em seu interior. $\mathrm{O}$ sindicalismo autêntico cresceu gradativamente sob a liderança política dos metalúrgicos do $\mathrm{ABCD}^{6}$ paulista. Sua composição, relacionada à construção e fundação do Partido dos Trabalhadores, ocorreu pela aliança de correntes políticas heterogêneas formadas por militantes de diferentes tendências políticas compostas por Socialistas, Comunistas, Trotskistas, sociais democratas, anarquistas, independentes, entre outras. Apesar das diferenças nas estratégias e formação política das tendências no sindicalismo autêntico, a existência de um inimigo único, o governo militar-civil e as frações de classe burguesas que o apoiavam, possibilitou a construção de alianças políticas de concepções distintas.

A expansão do novo sindicalismo no final dos anos 70 do século XX é fundamental para a análise da greve dos petroleiros. Seu crescimento foi acompanhado pela crise econômica e política internacional e seus impactos em nível nacional. Na prática, enquanto o sindicalismo nos Estados Unidos e na Europa sofreu grande revés em virtude da recessão econômica, elevação dos índices de desemprego e o endurecimento governamental e patronal das relações sindicais inspiradas nos princípios neoliberais, o Brasil, mesmo atingido por essa mesma crise, vivenciou caminho inverso.

O enfraquecimento político da ditadura militar-civil acompanhado pelo crescimento dos movimentos sociais fortaleceu os discursos críticos ao regime na sociedade. Devemos notar que o Brasil, na década de 1970 , contava com $11 \%$ da força de trabalho assalariada sindicalizada, sendo que, no final da década seguinte, esse número elevou-se para $32 \%{ }^{7}$ Em 1983 foi fundada a Central Única dos Trabalhadores, consolidando a luta dos trabalhadores pela conquista das oposições sindicais nos centros produtivos mais avançados do Brasil.

O crescimento do sindicalismo autêntico, a anistia, o abandono do governo militarcivil à política de substituição de importações e a influência do Fundo Monetário Internacional na economia brasileira contextualizaram o início da contraditória década de 1980. Para os movimentos sociais, uma "década vitoriosa" composta de avanços organizativos e sociais e, para as frações de classe burguesa nacionais, a "década perdida", à qual as mudanças econômicas internas no Brasil não acompanharam a reestruturação produtiva e as formas reconstrutivas de reprodução e acumulação do capital mundializadas.

O processo de reestruturação no sindicalismo brasileiro é fundamental para a análise das greve dos petroleiros de 1983. Em que pese o crescimento do novo sindicalismo no país, no ramo petroleiro essa concepção não contava com muitos adeptos. Apenas os duas bases petroleiras que realizaram a greve - Paulínia e Mataripe - eram representadas por sindicatos autênticos. A predominância de sindicatos corporativos no ramo petrolífero reduziu a capacidade de mobilização dos trabalhadores da Petrobrás como o governo militar-civil restringindo a resistência basicamente aos dois sindicatos citados anteriormente.

\section{O conflito petroleiro de 1983}

A decretação da greve ocorreu em meio a um complexo cenário econômico e político internacional com forte influência no Brasil. Em uma assembleia com mais de seiscentos trabalhadores foi aprovado o seu início para o dia seis de julho de 1983, trazendo como reivindicação a garantia no emprego, revogação do decreto Lei № 2036 , o rompimento com o Fundo Monetário Internacional e o fim do "arrocho salarial". Essa era uma pauta difícil de ser conquistada em virtude da conjuntura de crise internacional. A falência do Sistema de Bretton Woods, a guerra entre o Irã e o Iraque, as pressões do FMI 
visando conter, em face ao empobrecimento dos países periféricos, a moratória no pagamento dos juros da divida externa e o dócil e fragilizado papel do Brasil no cenário político internacional vigente marcaram o período em questão.

O processo de paralisação das atividades na indústria do petróleo é complexo e arriscado, estendendo-se em várias horas em sua total execução. Os equipamentos devem ser parados e resfriados aos poucos, bem como a quantidade de petróleo e derivados em processamento. Além disso, os operadores de Refinaria teriam o confronto com a administração local da empresa que tentaria evitar a parada da produção. Em um contexto de paralisação, entra em discussão a possibilidade do desabastecimento da população e das fábricas e, em especial, o escoamento de toda a produção nacional. Essa relação poderia favorecer os petroleiros em caso de uma possível negociação.

A rendição dos turnos de trabalho era condição estratégica para a greve que se iniciava. Além da pressão da direção da estatal, o receio da direção sindical era que a Petrobrás conseguisse deter dois turnos de trabalho no interior da Refinaria, promovendo o revezamento e a continuidade da produção. Como estratégia, os sindicalistas resolveram iniciar a greve oito horas antes do previsto, começando uma dura jornada do grupo de trabalho que permaneceria no interior das refinarias.

O objetivo sindical foi exaurir fisicamente os petroleiros em turno de trabalho, obrigando, com isso, a direção empresarial a parar a produção por falta de segurança. Esteva em disputa o controle da produção pelos trabalhadores, condição essencial para uma rápida negociação com a direção da empresa e o governo militar-civil.

O início da greve foi marcado pela truculência e repressão governamental ao movimento dos petroleiros. No dia posterior ao início da greve, - 7 de julho de 1983 - o então Ministro do Trabalho, Murilo Macedo, cassou o sindicato, visando quebrar a representação dos trabalhadores. A produção da Replan foi interrompida e, com isso, o governo intensificou a repressão à greve.

O processo repressivo foi acompanhado por uma estratégia midiática voltada a mobilizar a população contra os trabalhadores em greve. O princípio da quebra da solidariedade orgânica com inspiração epistêmica durkheiminiana foi o fundamento utilizado para a disseminação dos prejuízos que a greve poderia ocasionar à população, omitindo que ela atentaria principalmente à dinâmica da produção e circulação das mercadorias afetando as formas acumulativas do capital em sua forma produtiva e financeira. As propostas presentes na pauta de reivindicações atingiram não só interesses burgueses nacionais expressos por um governo com forte apelo bonapartista, bem como aos interesses dos grandes credores internacionais, em sua maior parte banqueiros privados estadunidenses, representados politicamente pelo Fundo Monetário Internacional.

A reorganização das formas de acumulação do capital em âmbito internacional implicou pressão política sobre os países periféricos manifesta na adoção de formas monetaristas de regulação da economia como condição para a concessão de novos empréstimos. Esteve em jogo formas de reprodução e acumulação do capital financeiro manifesto na cobrança de juros sobre juros. Os países centrais visaram resolver os impactos da crise em suas economias não se importando com a elevação da pobreza na periferia do capitalismo. Na prática, o conflito que se iniciou foi de resistência a uma fase embrionária do projeto neoliberal no Brasil.

Essa dinâmica internacional relacionada ao cunho ditatorial instalado no Brasil legitimou a repressão governamental à greve sustentado por Leis construídas pelo Estado Nacional isento da neutralidade e desprovido de sobrenaturalidade.

No dia sete de julho os trabalhadores da Refinaria de Mataripe na Bahia aderiram ao movimento com cerca de dois mil trabalhadores ocupando as instalações da estatal, após 
o enfrentamento com a polícia. Em São José dos Campos, os empregados da Petrobrás ameaçam paralisar as suas atividades, mas foram espancados pela polícia. As Refinarias de Cubatão, Minas Gerais e Paraná declaram solidariedade. Os metalúrgicos do ABCD aderiram à paralisação realizando uma greve de um dia nas empresas montadoras de automóveis em solidariedade aos petroleiros. Ficou definida uma greve "arrastão", em que os trabalhadores sairiam em passeata e forçariam o fim das atividades em todas as fábricas que encontrassem no caminho.

O Estado e a direção da empresa permaneceram intransigentes em não negociar. Shigeaki Ueki, presidente da Petrobrás, veio a Replan incumbido de pressionar os trabalhadores a voltar ao trabalho. A estratégia foi enviar gerentes com cargos administrativos acompanhados de policiais federais à casa dos funcionários ameaçando-os de demissão caso não retornassem ao trabalho.

As bases epistêmicas durkeiminianas manifestas na Doutrina de Segurança Nacional expressas no entendimento das greves como uma anomia social embasaram a ação e pensamento do governo militar-civil. O crescimento dos movimentos sociais no Brasil, a contestação dos resultados econômicos governamentais, a conjuntura internacional desfavorável e a proximidade das eleições fundamentaram esse confronto. A punição dos trabalhadores apresentou-se como estratégia efetiva de manutenção de sua autoridade política em âmbito nacional e resposta efetiva de controle social aos órgãos internacionais, merecendo destaque o próprio FMI.

O governo militar-civil utilizou-se de parcela da imprensa para influenciar a opinião pública contra a greve. O S.N.I. (Serviço Nacional de Informações) e o Dentel (Departamento Nacional de Telecomunicações) proibiram qualquer cobertura ao vivo da greve. $\mathrm{O} 2^{\mathrm{o}}$ Exército entrou em prontidão e a polícia reprimiu toda manifestação favorável aos petroleiros.

No dia nove de julho foram demitidos cem petroleiros em Paulínia e cento e oitenta em Mataripe, criando o "terror" para uma categoria profissional que não conhecia em seu cotidiano de trabalho a demissão por "justa causa" e o consequente desemprego. Ao mesmo tempo em que a repressão estatal à greve cresceu, os petroleiros de Paulínia e Mataripe não conseguiram a adesão de outras refinarias à paralisação. No estado de São Paulo, os petroleiros de Cubatão vinculados à Refinaria Presidente Bernardes - RPBC -, a primeira grande refinaria da Petrobrás fundada em 1955 e terminais petrolíferos não aderiram à greve. Da mesma forma, a mobilização de apoio dos metalúrgicos do $\mathrm{ABCD}$ também terminou. A assembleia que confirmou o fim da paralisação dos metalúrgicos do ABCD ocorreu no gramado do estádio da Vila Euclides, com centenas de trabalhadores de diferentes cidades do estado de São Paulo. Estava em debate a organização de uma greve geral contra o governo Figueiredo, envolvendo um maior número de trabalhadores e categorias profissionais, bem como a própria criação da Central Única dos Trabalhadores.

As primeiras listas de demissão acompanhadas pela retirada do apoio de outros sindicatos isolaram os petroleiros afetando a sua resistência. A greve durou sete dias, com atividades culturais e políticas na espera de uma saída negociada para o impasse. Não era mês de data base e o movimento possuiu forte conotação de enfrentamento transcendente às fronteiras nacionais. O fim da greve ocorreu depois de concorrida assembleia, no dia onze de julho de 1983 contabilizando 152 demissões em Paulínia e 189 na Bahia.

A intimidação dos trabalhadores continuou mesmo após o final da greve. A administração local da Estatal criou filas de identificação na porta das refinarias e palestras de "conscientização empresarial" para a discussão das consequências do movimento. A direção da Petrobrás afirmou que aquele era um exemplo de que os trabalhadores não deveriam se envolver com o sindicato, pois militância era sinônimo de demissão. 
Petroleiros foram demitidos no local de trabalho logo após o término da greve, outros depois do expediente, criando a expectativa funesta da divulgação de novas listas de demissão.

A greve, entendida como uma "patologia social", princípio central da Doutrina de Segurança Nacional - DSN -, contrapôs as políticas liberalizantes do Fundo Monetário Internacional, condição essencial para o sucesso das negociações do Brasil com os credores internacionais para a obtenção de novos empréstimos para o pagamento dos juros da dívida externa brasileira. Ao mesmo tempo, as vitórias eleitorais dos candidatos oposicionistas ao governo militar em 1982 colocaram os estrategistas do regime em contradição. Demonstrar, por um lado, que o seu poder de repressão era efetivo e, por outro lado, conciliar as divisões internas dentro de sua base de sustentação já não unânime quanto a sua continuidade na sociedade brasileira.

A greve dos petroleiros de 1983 demonstrou que um complexo processo econômico esteve em construção no Brasil, o embrião de propostas neoliberais que se materializariam na década de 1990. O Decreto Lei $n^{0} 2036$ foi utilizado como exemplo para a construção de discursos e ações políticas de cunho ideológico, voltados à vulgarização do Estado Nacional, das Estatais, dos funcionários públicos e da política de substituição de importações existentes desde Juscelino Kubitschek até o II Plano Nacional de Desenvolvimento - PND -.

\section{A greve dos petroleiros de 1983 contra o Governo Figueiredo e o FMI: considerações teóricas.}

Marx afirma em A Miséria da Filosofia que as categorias econômicas não são senão expressões teóricas, abstrações das relações sociais de produção. Entende que as relações sociais estão intimamente ligadas às forças produtivas. Adquirindo novas formas produtivas, os homens mudam o seu modo de produção, e mudando o modo de produção, eles mudam todas as relações sociais.

Essa formulação fundamenta a analise da greve dos petroleiros de 1983 como expressa em uma totalidade, manifesta por rupturas e continuidades, um processo dinâmico e em transformação impulsionado pelos conflitos humanos manifestos pela luta de classes. Marx, em o "Método da Economia Política" apontou os elementos isolados não se explicam por si só, mas sim em uma ampla relação existente nos sistemas econômicos:

[...] que se elevam do simples, tal como trabalho, divisão do trabalho, necessidade, valor de troca, até o Estado, a troca entre as nações e o mercado mundial. O último método é manifestamente o método cientificamente exato. $\mathrm{O}$ concreto é concreto porque é a síntese de muitas determinações, isto é, unidade do diverso. Por isso o concreto aparece no pensamento como o processo da síntese, como resultado, não como ponto de partida, ainda que seja o ponto de partida efetivo e, portanto, o ponto de partida também, da intuição e da representação. ${ }^{8}$

Kosic (1976, p.49) entende que a dialética não é uma totalidade como um todo já feito e formalizado que determina as partes. À própria determinação de totalidade pertencem a gênese e o desenvolvimento da totalidade. Ela não é um todo já pronto recheado com conteúdo. Na qualidade das partes com suas múltiplas relações, a totalidade se concretiza e esta concretização não é apenas construção de conteúdo, mas também criação do todo. A sua criação como estrutura significativa é, portanto, ao mesmo tempo, um processo no qual se constrói realmente o conteúdo objetivo e o significado de todos os 
seus fatores e partes. A totalidade enquanto processo em construção tem como pressuposto a marcha da história e das lutas sociais produzidas.

A totalidade é um processo que se explica no movimento da história impulsionada pela luta de classes. Isso implica na recuperação das aspirações, projetos e objetivos das classes que compõem a sociedade e, consequentemente, a composição heterogênea de suas frações, sendo a burguesia um exemplo. É assim que afirma Marx:

As categorias que exprimem suas relações, a compreensão de sua própria articulação, permitem penetrar na articulação e nas relações de produção de todas as formas de sociedade desaparecidas, sobre cujas ruínas e elementos se acham edificada, e cujos vestígios, não ultrapassados ainda, levam de arrastão desenvolvendo tudo que fora antes apenas indicado que toma assim toda a sua significação etc. A anatomia do homem é a chave da anatomia do macaco. O que nas espécies animais inferiores indica uma forma superior não pode, ao contrário, ser compreendido senão quando se conhece a forma superior. A Economia burguesa fornece a chave da Economia da Antiguidade etc."

A heterogeneidade de frações de classe burguesa expressaram as relações entre o governo Figueiredo e o FMI. Ambos os setores representavam setores da burguesia com interesses diversificados em disputa entre si. A fragmentação da burguesia nacional e internacional não implica necessariamente na negação do capitalismo e da reprodução do capital. Na prática, o fracionamento em virtude da disputa por interesses antagônicos é abandonado em períodos aos sua hegemonia é ameaçada. A fragmentação e a conciliação são as expressões maiores da composição interna da classe burguesa.

Marx em "O Capital" demonstrou que quanto maior é a concorrência e a competição no interior da classe dominante, maior será a concentração do capital. A centralização levará a crises que ocorrerão em intervalos cada vez mais curtos. "[...] a burguesia, desde o estabelecimento da grande indústria e do mercado mundial, conquistou, finalmente, a soberania política exclusiva no Estado representativo moderno. O governo moderno não é senão um comitê para gerir os negócios comuns de toda a classe burguesa" (Marx; Engels, 1983, v. I, p. 23)

Em "As Lutas de classes na França (1848-1850)" e, principalmente, em o "O dezoito brumário de Luís Bonaparte", Marx demonstrou a relação de representação do Estado para com a burguesia. A burocracia estatal desenvolve formas de cooptação dos trabalhadores, produzindo uma burocracia que se estende além da consciência burguesa. Mesmo suas ações ferindo os interesses burgueses em determinado período da história se justificam na manutenção da ordem e formas de reprodução e acumulação do capital. Entre as formas de representação do Estado aos interesses burgueses se destaca duas atuações principais. Primeiro, a existência de uma burocracia militar civil voltada aos interesses da burguesia, seja na preservação da ordem, seja por financiamentos, contratos, etc. Segundo, através do oferecimento de serviços sociais como forma de evitar, ou mesmo controlar a luta de classes.

A composição fracionária da burguesia manifesta nas disputas entre o governo Figueiredo e o FMI fundamenta a greve dos petroleiros de 1983. Em que pese o caráter fragmentário da burguesia nacional e internacional, uma ação comum unificou todas as suas frações: a negação à resistência e às lutas dos trabalhadores em qualquer país gerido pela lógica reprodutiva do capital. A greve dos petroleiros de 1983 teve contra si a repressão do decadente Governo Figueiredo manifesta por ameaças e demissões dos trabalhadores que dela participaram. Essa ação foi justificada através da produção de 
ideologias de criminalização da resistência, tendo parcela considerável da mídia como grande aliada.

A greve dos petroleiros se contrapôs ao Fundo Monetário Internacional, representante dos prestamistas internacionais que apostavam na liberalização das economias dos países periféricos como forma de superar a crise econômica em curso nos países centrais. Na realidade, a ação subordinada do governo Figueiredo no cenário político internacional o colocou como um mero instrumento que garantisse os interesses produtivos e financeiros internacionais.

Marx afirma que o estudo de uma sociedade implica na superação da aparência dos processos sociais, remetendo-os à essência daquilo que eles realmente são. Na prática, esse processo é possível através da própria formação da burguesia, recuperando suas frações de classe e remetendo-as na produção e, ao mesmo tempo, nas relações de produção que elas estabelecem na superestrutura da sociedade. Essa é a condição em que se apresenta a complexidade da luta de classes e projetos de sociedade nela inseridos.

O Governo Figueiredo, a crise do petróleo, o FMI, a recessão estadunidense, a liberalização das economias dos países periféricos como condição para a obtenção de empréstimos para o pagamento de juros da dívida externa não eram entendidas como um movimento em sua totalidade pelo movimento sindical combativo. $\mathrm{Na}$ prática, as mediações acima foram entendidas como isoladas e não como um amplo processo de reestruturação do capitalismo, expresso no que Harvey denominou como acumulação flexível. Da mesma forma, a discussão sobre as contradições internas e externas manifestas no empobrecimento dos países periféricos e seus impactos na economia e na política estadunidense eram restritas a centros acadêmicos, distantes do debate e, principalmente, da formação política dos trabalhadores brasileiros, merecendo destaque, os petroleiros.

A não compreensão desse processo deu um tom metafísico às disputas em questão. O FMI foi entendido como uma espécie de "agente do mal" que se explicava por si mesmo, cuja resolução de todos os problemas nacionais passaria apenas por sua negação, algo que apenas não se concretizava por ausência de "vontade política" governamental. Foi essa falta de percepção do processo em questão que atribuiu ao governo Figueiredo uma autonomia política que não tinha e um ator central que na realidade não o era.

A pauta de reivindicações dos petroleiros teve por objetivo pressionar o governo militar-civil a não embarcar na "Barca de Caronte" e seus efeitos nefastos para o Brasil. Porém, o que os trabalhadores não perceberam era que o país já embarcara nesta "viagem" há quase uma década. A fragilidade governamental demonstrou a impossibilidade deste desembarque, visto que os interesses das frações de classe burguesa apoiavam os rumos tomados. Podemos dizer que enquanto os lucros e dividendos dessas frações burguesas foram elevados, ocorreu o nítido apoio ao governo militar-civil. Porém, com o cenário da crise internacional, a entrada do país em crise e a ineficiência governamental em manter os índices de desenvolvimento fizeram com que esse apoio fosse gradativamente retirado.

A frações de classe burguesa tem como objetivo a reprodução do capital e concentração de riquezas sobre o seu domínio. Não importa que para isso os projetos governistas sejam de âmbito nacional ou transnacional. Enquanto seus lucros proliferam, "e viva a Doutrina de Segurança Nacional e seus respectivos os Atos Institucionais", Porém, quando essa condição não mais existe, "apoio às Diretas Já" vamos superar "a década perdida" e a incompetência militar.

Na prática, a greve parcial de uma única categoria profissional teve poder político limitado em barrar este processo mundializado, cuja resistência, tomando como referência sua amplitude, teria maior possibilidade de êxito através de uma organização dos trabalhadores em âmbito internacional. Os petroleiros estavam em disputa contra frações 
de classe burguesa vinculadas à reprodução do capital, principalmente, em sua forma financeira cuja ação se explica na circulação do capital em âmbito internacional.

Marx desenvolveu estudos sobre a reprodução e circulação do capital financeiro, denominado em sua obra como capital bancário. Em o livro III de "O capital" demonstrou que o capital existente nos Bancos Centrais Nacionais é composto em parte pelo estatal e, em outra parte, pelo depósito realizado pelos bancos privados. Essa composição mista do capital bancário estatal traz implicações ao sistema financeiro, uma vez que a crise do sistema privado afeta o sistema estatal, pois ambos são relacionados. Esse é o sentido ao qual se explica o temor do FED sobre a possibilidade de calote da dívida externa dos países periféricos. Tomando como referência uma sociedade mundializada em nível econômico e globalizada em sua expressão cultural, as formas reprodutivas do capital tomam uma dimensão internacional através da qual a resolução dos problemas de um país passa pela ação de outro.

A greve dos petroleiros de 1983 confrontou esse processo internacional, tomando uma dimensão maior do que aparentou ser. Ela atentou contra um amplo processo de reestruturação capitalista em curso desde os anos 60 do século XX manifesta em um processo gradativo do crescimento reprodutivo do capital em sua forma financeira. Essas formas reprodutivas do capital bancário implicaram na garantia do retorno dos investimentos incorporando ao valor-trabalho a acumulação em forma de juros.

Marx teorizou em o Livro III de "O capital" que parte do capital bancário é investida em papéis portadores de juros. Ela mesma constitui parte do capital de reserva que não funciona no negócio bancário real. A parte mais importante consiste em letras de câmbio, isto é, promessas de pagamento de capitalistas industriais ou comerciantes" [...] Para o prestamista de dinheiro, essas letras de câmbio são papéis portadores de juros: ao comprá-las, ele deduz o juro pelo tempo que falta até o vencimento. Isso é o que se chama descontar. Depende, pois, da taxa de juros em cada momento a grandeza da dedução da soma que a letra de câmbio representa." (Marx, 1988: 6) A outra parte do capital bancário é formada pela reserva em ouro ou mesmo dinheiro. Essa é a condição do banco para garantir a disponibilidade dos depósitos aos depositantes. Esse capital bancário está sempre em flutuação, uma vez que quando são retirados depósitos por alguns, por outros, nova quantia é depositada.

Os fundos de reserva dos bancos, em países de produção capitalista desenvolvida, expressam sempre, em média, a grandeza do dinheiro existente como tesouro, e parte desse tesouro consiste, por sua vez, em papéis, meros direitos sobre ouro, mas que não constituem valores em si. A maior parte do capital bancário é, portanto, puramente fictícia e consiste em títulos de dívidas (letras de câmbio), títulos de dívida pública (que representam capital passado) e ações (direitos sobre rendimento futuro). Não se deve esquecer que o valor monetário do capital que esses papéis nas caixas fortes do banqueiro representam - mesmo à medida que são direitos sobre rendimentos seguros (como no caso dos títulos da dívida pública) ou à medida que são títulos de propriedade de capital real (como no caso das ações) - é completamente fictício e que é regulado de modo a se desviar do valor do capital real que, pelo menos parcialmente, representam; ou onde representam mero direito a rendimentos e não capital, o direito ao mesmo rendimento se expressa num montante sempre variável de capital monetário fictício. Além disso, esse capital fictício do banqueiro, em grande parte, não representa seu próprio capital, mas o do público, que o deposita com ele, com ou sem juros. (Marx, 1988: 7) 
As formas de composição do capital bancário expressas na organicidade entre o estatal e o privado fundamenta as relações econômicas e políticas entre os bancos demonstrando que a dificuldade de um segmento pode levar ao colapso de outro segmento bancário. As expressões demonstradas por Marx justificam o temor de frações de classe dos países centrais do calote dos países periféricos levando o FMI a assumir o papel de gestor da dívida externa com apoio da burguesia internacional. Por um lado, o endurecimento das condições para a concessão de novos empréstimos como garantia do retorno do investimento manifesto na reprodução do capital composto de juros como estratégia para a superação da crise econômica nos países centrais, merecendo destaque os Estados Unidos. Por outro, a naturalização do FMI como uma espécie de "intermediário honesto" impondo, como única alternativa, a liberalização das economias dos países periféricos como forma de superação da crise no interior de suas fronteiras. Essa liberalização da economia atendeu aos interesses do capital internacional em busca de facilidades não só para o acesso a matérias primas, bem como fomentar a produção garantindo a circulação mundializada das mercadorias produzidas em suas fronteiras.

A greve de 1983 se contrapôs para além do embate com o governo militar-civil, atingindo, isso sim, os interesses dos banqueiros privados estadunidenses. Estava em curso uma estratégia de frações de classe burguesa vinculadas ao capital financeiro voltada à estabilidade econômica e política dos EUA a qualquer custo, cuja conta deveria ser paga pelos países periféricos dependentes de fundos internacionais para equilibrar suas balanças de pagamentos. Os petroleiros se contrapuseram a um vantajoso negócio internacional através do qual o próprio dinheiro se transformava em mercadoria. A concessão de novos empréstimos aos países periféricos tinha como objetivo garantir a continuidade do pagamento dos juros expressos em uma dívida crescente. Em outras palavras, uma cirande financeira expressa em juros cobrados sobre outros juros pré-existentes, gerando a necessidade de novos empréstimos, e assim adiante.

Marx desenvolveu em "o Livro III de O capital" reflexões sobre o acúmulo do capital remetendo-o a processos maiores inerentes às formas de circulação e a obtenção de mais-valia. As reflexões de Marx sobre as crises cíclicas do capital são fundamentais para a recuperação de suas formas de reprodução expressas nas mediações entre a taxa de lucros e juros nas transações comerciais. Tomando como referência os pressupostos expressos no "Método da crítica à economia política" através do qual o particular se explica no geral, a formulação do capital e suas formas de reprodução se explicam pelas contradições que o antecederam manifestas na constituição do trabalho, tanto na sua forma produtiva, como improdutiva.

Esta discussão ganha relevância nas formulações teóricas elaboradas por Marx tanto no Livro II de O Capital, como no Livro III, onde se destaca a teoria marxiana monetarista. A recuperação histórica do capital portador de juros é percebida através dessa complexidade. Marx recupera as origens do capital financeiro demonstrando que sua questão central consiste na transformação do dinheiro em capital e este capital como à expressão pertinente à produção capitalista que através da exploração da compra da força de trabalho obtém mais-valia do trabalho alheio.

O trabalho produtivo produz não só o valor necessário à reprodução da força de trabalho do trabalhador, como também a mais-valia, o valor excedente do qual se origina o lucro dos diferentes capitais, os juros, aluguéis e rendas de todos os tipos, além dos gastos improdutivos tanto públicos como privados. Entre estes gastos improdutivos incluem-se até mesmo o salário dos trabalhadores improdutivos. Assim, os salários pagos aos trabalhadores improdutivos implicam uma dedução do 
excedente produzido na sociedade. Não só não produzem mais-valia, como reduzem (ou melhor, consomem parte da) a massa total dela gerada pelos trabalhadores produtivos. Além disso, todos os gastos de materiais, sejam matérias primas e auxiliares, sejam os referentes à depreciação do capital fixo que implicam, também constituem destruição de excedente real produzido pelos produtivos, redução, portanto da massa de maisvalia disponível para distribuição entre as diferentes camadas da sociedade que dela recebem seus rendimentos. (Carcanholo, s/d: 3 )

A recuperação dessas relações é relevante para a crítica às formas de acumulação vigentes na sociedade capitalista, especialmente quando tomamos por referência o crescimento do capital especulativo que redefine a relação entre nações, acentua a luta de classes e impõe formas perversas de obtenção de mais-valia oriundas do trabalho. Marx teorizou uma formulação crítica de como o capital se reproduz, sua composição e, consequentemente, os processos desumanizantes por ele criado. Para isso, desenvolveu formulações voltadas à explicar a organicidade compositiva do capital. Entre essas formulações merece destaque a constituição do capital industrial.

O capital industrial é aquele vinculado às indústrias onde se dão a compra da força de trabalho e a produção de mercadorias. Em o livro III de "O Capital" demonstrou a complexidade do conjunto de relações comerciais executadas na sociedade. "De outro ponto de vista, a atividade comercial é mais ampla do que normalmente se considera. Ela inclui uma série de operações relacionadas com o dinheiro como guarda, pagamentos e recebimentos, cobrança, compensação, que são típicas do setor bancário. Marx chama o capital dedicado a essas operações de capital de comércio de dinheiro (forma de capital comercial)" (Carcanholo, s/d: 11).

$\mathrm{O}$ entendimento das questões acima apresentadas é fundamental para a recuperação do conceito de juros expresso nas reflexões marxianas. Marx afirma que no lugar:

[...] da efetiva transformação de dinheiro em capital desponta apenas sua forma sem conteúdo. Como no caso da capacidade de trabalho, o valor de uso do dinheiro se transforma no valor da capacidade de criar valor de troca maior do que o possuído. É emprestado como valor que se valoriza a si mesmo, mercadoria, mas uma mercadoria que se distingue da propriedade como tal precisamente por essa propriedade, possuindo, portanto, também, uma forma particular de alienação (...) O que de fato é vendido é seu valor uso, que neste caso consiste em pôr valor de troca, produzir lucro, produzir maior valor do que o possuído por ele próprio. Como dinheiro, não se modifica pelo uso. Mas como dinheiro é gasto e como dinheiro reflui (Marx, 1978, p. 135)

Marx demonstra ainda em "O capital" que a relação entre o juro e a mais-valia se explica na circulação do capital manifesta na relação econômica de empréstimos concedidos ao capital industrial para ser investido na produção. Esse movimento cria uma relação através da qual dos próprios lucros gerados pela obtenção da mais-valia no processo produtivo, uma parte é retirada para o pagamento dos juros dos empréstimos realizados. O capital monetário é o desdobramento desse processo. Ele não se constitui em mera abstração, mas assume uma relação social em suas formas reprodutivas similares àquelas existentes na circulação de mercadorias.

A demanda de capital monetário provém da necessidade de alguns capitalistas de acelerar a rotação do seu capital (o capital monetário é 
usado para antecipar a transformação do capital-mercadoria), ou então, como capital adicional, que será transformado em meios de produção para uma reprodução ampliada. A oferta de capital monetário provém do dinheiro ocioso, que pode ser colocado a cargo de capitalistas atuantes, para que se dê sua valorização. Os mecanismos pelos quais o capital monetário é ofertado estão mais bem descritos na análise do sistema financeiro. (Chociay; Neves: 3 )

As mediações entre o capital comercial e o capital financeiro, demonstradas por Marx em O Livro III de O Capital, constituem fundamentos para a recuperação da origem de formas de reprodução expressas pelo capital manifesto na constituição de juros. "O comércio de dinheiro atinge seu pleno desenvolvimento, o que sempre se verifica nas suas origens, quando às suas demais funções se associam as de emprestar, de tomar emprestado e de negociar com crédito.".(Marx, p. 369)

O desenvolvimento do capital fictício é impulsionado pelo sistema de crédito proporcionado pelos bancos atuando no mercado. Isso se explica por um também complexo processo de circulação através do qual os próprios capitalistas fornecem a um banco seu dinheiro em forma de depósitos e contraem deste mesmo banco crédito através de empréstimos. Marx em o Livro III de O capital demonstrou essa relação ao afirmar que todo o valor monetário convertido em depósito bancário acaba por se tornar em capital monetário para empréstimos, gerando capital fictício. "Com o desenvolvimento do capital portador de juros e do sistema de crédito, todo capital parece duplicar e às vezes triplicar pelo modo diverso em que o mesmo capital ou simplesmente o mesmo título da dívida aparece, em diferentes mãos, sob diversas formas. A maior parte desse "capital monetário" é puramente fictícia" (Marx, 1983d, p. 14).

A constituição do capital composto de juros implica em um movimento deste mesmo capital expresso na auto-expansão do valor por ele mesmo criado. Marx, em o Livro Terceiro de $\mathrm{O}$ capital apresentou essa relação a transição da mercadoria em dinheiro e, consequentemente, da reprodução do dinheiro em dinheiro. É assim que a circulação D M - D', com o incremento da reprodução do capital intermediada pelos juros, acaba por criar formas de reprodução que precedem do intermédio da mercadoria, manifesto na formulação D - D'.

Marx representou a relação entre o capital bancário e o produtivo através da elaboração de uma equação expressa da seguinte forma: $\mathrm{D}-\mathrm{D}-\mathrm{M}-\mathrm{D}^{\prime}-\mathrm{D}^{\prime}$. Nas relações entre os capitalistas, aqueles vinculados ao monetarismo - os prestamistas emprestam dinheiro a outros capitalistas garantido pelas vias jurídicas para esse fim. $\mathrm{O}$ prestamista "A" ao emprestar dinheiro para o capitalista ativo "B", promove uma forma de circulação de capital, através da qual, em poder de "B", o dinheiro se transforma em capital, percorrendo o circuito D - M - D', voltando ao capitalista "A" como D'. Em outras palavras, é devolvida ao capitalista inicial não o lucro inteiro, mas apenas parte do lucro, o juro. "Na realidade é somente a separação dos capitalistas em capitalistas monetários e capitalistas industriais que converte parte do lucro em juros e cria, em geral, a categoria do juro (Marx, 1983, p. 277)."

Mas, além da soma de capital, B tem de entregar a A parte do lucro obtido com essa soma de capital sob o nome de juro, pois A só lhe deu o dinheiro como capital, isto é como valor que não apenas se conserva no movimento, mas cria mais-valia para seu proprietário. Permanece nas mãos de B apenas enquanto é capital funcionante. E com seu refluxo - no fim do prazo estipulado - deixa de funcionar como capital. Como capital 
não mais funcionante tem de ser devolvido a $\mathrm{A}$, que não cessou de ser o proprietário jurídico do mesmo. (Marx, 1983c, p. 257)

Na prática, com o estabelecimento do sistema de crédito, tanto os juros, como o capital industrial apresentam-se como uma unidade, assumindo uma dimensão sobrenatural que omite as relações sociais expressas pelo trabalho que foram responsáveis por sua constituição. A mais-valia se restringe ao capitalista industrial. Os prestamistas que detêm o dinheiro alienam esse mesmo dinheiro a outro capitalista, desta vez como capital manifesto na possibilidade de criação de mais-valia. Ele empresta constantemente seu capital garantindo para isso formas específicas para a sua reprodução.

Para Marx o capital como portador de juros atua de forma similar à mercadoria. "A maior ou menor valorização do capital portador de juros só é mensurável comparando o montante dos juros, a parte que lhe cabe do lucro global, com o valor do capital adiantado. Por consequência, se o preço expressa o valor da mercadoria, o juro expressa a valorização do capital monetário e aparece por isso como o preço que se paga pela mesma ao prestamista." (Marx, 1983, 266).

As relações entre capital bancário e produtivo se explicam nas ações e pressões internacionais para a concessão de empréstimos do FMI para o pagamento dos juros da dívida externa. Não foi ao acaso que as exigências do FMI atendiam à desregulamentação das economias nacionais dos países devedores, enfatizando os pressupostos hayekianos anteriormente apresentados.

O FMI ao determinar a abertura dos mercados nacionais dos países periféricos para a atuação de empresas transnacionais como condição para fornecer novos empréstimos agiu em defesa de frações de classe representantes tanto do capital produtivo, como pelo bancário. O que estava em jogo era forçar o Estado Nacional a editar leis nesse sentido, diminuindo o seu tamanho e poder de atuação através da venda de empresas estatais, diminuição seu poder de atuação e seu quadro efetivo de funcionários.

O Decreto Lei 2036, motivo principal da greve dos petroleiros de 1983, foi editado em consonância com esses pressupostos. Uma redefinição do Estado Nacional que implicava na precarização das condições de trabalho dos empregados das empresas estatais, fragilizados pelos resultados e metas que levaram ao fracasso do II PND, resultado dos imperativos do FMI como condição do oferecimento de novos empréstimos ao Brasil. É nessa trama internacional da elevação das formas acumulativas do capital expressas nas mediações entre o produtivo e o bancário que se inseriu a greve dos petroleiros de 1983.

Essa greve marcou de resistência dos trabalhadores a um processo internacional que traria sérios desdobramentos para o Brasil. Em que pese sua curta duração, ela alertou para a crítica a um processo de reestruturação capitalista como forma de superação da crise econômica internacional, cujo preço da estabilidade dos países centrais seria o crescimento da dívida externa, da pobreza e instabilidade social e política dos países periféricos.

Em virtude do conjunto de fatores e interesses em questão, essa foi uma greve que não teria como ser vencida em sua totalidade. Os petroleiros tiveram dificuldade em perceber que a luta contra o FMI implicou em algo similar à relação entre "David e Golias". Temos nossas dúvidas se uma greve geral no país conseguiria deter esse processo. As condições materiais para a ruptura com o modo de produção inexistiam, visto que os movimentos sociais acompanhavam a tendência existente no Brasil em um gradativo processo de transição burguesa que levaria às "Diretas Já" e a abertura democrática dois anos depois. Da mesma forma, derrotar os militares, abandonados por parcela significativa dos setores civis que o apoiaram aos quais não mais se interessavam se identificar com o 
regime dado sua ineficiência e atrocidades significaria cair no conto através do qual se imagina que se "derruba Roma derrotando apenas um mero Centurião".

Apenas uma parcela de trabalhadores da Petrobrás em greve não teria como parar esse complexo processo internacional em curso no período, envolvendo atores de diferentes continentes. Essas análises poderiam levar ao entendimento que a greve foi um equivoco e totalmente derrotada. Que os dirigentes sindicais em sua "ingenuidade" ou mesmo "ânsia" pelo poder pelo controle do Partido dos Trabalhadores e a futura Central Única dos Trabalhadores criaram uma armadilha que custou o emprego de centenas de petroleiros.

Ressaltamos que não acreditamos nessas afirmações. A posição subordinada do governo Figueiredo nas negociações internacionais com o FMI associada à debilidade econômica e política do Brasil apresentou possibilidades de um processo gradativo de demissões na estatal preparando-a para a futura privatização nos anos subsequentes. Os dirigentes sindicais não cometeram equívoco na interpretação do denominado "Pacote das Estatais". Ele foi a expressão da instauração gradativa de uma fase embrionária do neoliberalismo, cujos contornos tomariam novas dimensões na década de 1990.

A greve barrou os impactos do "pacote das estatais" na Petrobrás. Os demitidos foram readmitidos em 1985, e uma outra parcela nos anos subsequentes. Uma nova geração de militantes petroleiros foi formada no chão das refinarias, terminais e plataformas da Petrobrás. Esses trabalhadores reconstruíram e reestruturaram o Sindicato dos Petroleiros de Campinas de Paulínia, participando de greves históricas contra os frutos dessa fase embrionária do neoliberalismo que amadureceram na década de 1990. Deixemos estes estudos para outros trabalhos de pesquisa...

\section{Referências}

BRANT, Vinícius Caldeira, Paulínia: Petróleo e Política. S.P: Cebrap, 1990.

CARCANHOLO, R. A. O trabalho produtivo na teoria marxista. COMPLETAR

CHOCIAY, Henrique; Neves, Lafaiete Santos. O conceito de juros em Marx e Keynes e sua influência sobre os modelos de crises financeiras. In Contribuciones a la Economía" http://www.eumed.net/ce/2009a/csn.htm.

LUCENA, Carlos. Aprendendo na luta: a história do sindicato dos petroleiros de Campinas e Paulínia. SP: Publisher Brasil, 1997.

Marxismo, crise do capitalismo monopolista e qualificação dos trabalhadores. In Lombardi, J.C. e Saviani, D. Marxismo e Educação: debates contemporâneos. Campinas, Autores Associados, 2005.

Tempos de destruição: educação, trabalho e indústria do petróleo no

Brasil. Campinas, SP: Autores Associados, MG: Edufu, 2004.

Os tempos modernos do capitalismo monopolista: um estudo sobre a

Petrobrás e a (des) qualificação profissional dos seus trabalhadores.Tese de doutorado,

Faculdade de Educação : Unicamp, 2001.

MARX, Karl. As Lutas de Classes na França (1848-1850). São Paulo: Global, 1986.

"La Cuestión Judía", in: Escritos de Juventud. México: Fondo de Cultura Económica, 1987.

. Manuscritos Econômico-Filosóficos e Outros Textos Escolhidos. Seleção de

textos realizados por José Arthur Giannotti; Traduções conduzidas por José Carlos Bruni (et al.). $2^{a}$ edição, São Paulo: Abril Cultural, 1978.

. El Capital. Buenos Aires: Signos, 1971.

O capital: crítica da economia política. Tradução de Régis Barbosa e Flávio

R.Kothe. V.I. T.II São Paulo: Abril Cultural, 1983a. (Os Economistas). 
O capital: crítica da economia política. Tradução de Régis Barbosa e Flávio R.Kothe. v.II. São Paulo: Abril Cultural, 1983b. (Os Economistas).

. O capital: crítica da economia política. Tradução de Régis Barbosa e Flávio

R.Kothe. v.III. São Paulo: Abril Cultural, 1983c. (Os Economistas).

- O capital: crítica da economia política. Tradução de Régis Barbosa e Flávio

R. Kothe. v.III. t.II. São Paulo: Abril Cultural, 1983d. (Os Economistas).

O 18 Brumário de Luís Bonaparte. São Paulo: Paz e Terra, 1997

Para a Crítica da Economia Política , Salário Preço e Lucro e o rendimento e

suas Fontes. São Paulo: Abril Cultural, 1982.

MARX, Karl, Engels, Friedrich. Obras escolhidas I, II e III. São Paulo: EditoraAlfaOmega, 1983.

La Ideologia Alemana. Montevideo: Grijalbo, 1974.

$\mathrm{O}$ governo Figueiredo: o fim do desenvolvimentismo "à brasileira http://www.centrocelsofurtado.org.br/arquivos/image/201109011001560.MD4_0_179.pdf acesso dia 12/05/2013 15 horas

SILVA, Antonio Ozai da, História das Tendências no Brasil. S.P: Ed. Editorial, 2ª ed. s/d

\section{A) Documentos e Jornais Sindicais}

Ata de Fundação da Associação dos Petroleiros de Campinas e Paulínia, 1972.

Ata de Fundação do Sindipetro Campinas e Paulínia, 1973.

Atas das Reuniões Sindicais do Sindipetro Campinas e Paulínia de 1973 até 1983.

Boletins O Petroleiro, 1983 Até 1995.

Dossiê sobre a greve de 1983, elaborado pela direção do Sindipetro Campinas.

\section{B) Jornais e Revistas}

Jornal Correio Popular -(1983/ 1995)

Jornal Diário do Povo -(1983/1995)

Jornal Folha de São Paulo - (1983/1995)

Jornal Gazeta Mercantil - (1983/1995)

Jornal O Estado de São Paulo - (1983/1995)

Notas

\footnotetext{
${ }^{1}$ Pós-doutorado em Educação Ufscar. Doutor em Filosofia a História da Educação Unicamp. Professor do PPGED e do PPGEC /Faced/UFU. Membro da Linha de Pesquisa Trabalho Sociedade e Educação. Bolsista de Produtividade 2 do CNPQ.

${ }^{2}$ Doutora em Educação pela UFU. Professora da Esamc e da Unipac Uberlândia.

3 Doutora em Sociologia Unicamp. Professora do PPGED/Faced/UFU. Membro da Linha de Pesquisa Trabalho Sociedade e Educação. Pesquisadora Fapemig.

${ }^{4}$ Doutor em Educação Unesp. Professor do PPGED e do PPGEC /Faced/UFU. Membro da Linha de Pesquisa Trabalho Sociedade e Educação. Pesquisador CNPQ.

${ }^{5}$ Doutora em Comunicação USP. Professora do PPGED e do PPGEC /Faced/UFU. Membro da Linha de Pesquisa Trabalho Sociedade e Educação. Pesquisador CNPQ.

${ }^{6}$ Santo André, São Bernardo, São Caetano e Diadema.

${ }^{7}$ Fonte: http://www1.folha.uol.com.br/folha/dinheiro/ult91u400883.shtml acesso dia 10 de novembro de 2012, às 20 horas.

${ }^{8}$ Karl Marx,http://www.insrolux.org/textosmarxistas/metododaeconomiapoilitica.htm

${ }^{9}$ Fonte: http://www.insrolux.org/textosmarxistas/metododaeconomiapoilitica.htm

Recebido em Novembro/2013

Aprovado em Dezembro/2013
} 